DOI https://doi.org/10.18551/rjoas.2020-10.28

\title{
THE EFFECT OF BANKING FINANCIAL RATIO ON THE DEVELOPMENT IN INDONESIA STOCK EXCHANGE
}

\author{
Yolanda*, Nieke Masruchiyah, Massora Agustina, Kurniati Arni \\ University of Borobudur, Jakarta, Indonesia \\ *E-mail: yolanda@borobudur.ac.id
}

\begin{abstract}
The purpose of this study to probes the connection between variables of financial performance and capital market development. It employs an analysis on the panel data of period of 2011-2017. The research findings show that: (1) Capital Adequacy Ratio (CAR), Loan to Deposits Ratio (LDR), Return on Asset (ROA), and Non-Performing Loan (NPL) notably affect the amount of issued stock and stock price, (2) Return on Asset (ROA), Capital Adequacy Ratio (CAR), Earning per share (EPS), and Debt to Total Assets (DTA) significantly influence market capitalization. (3) Net Interest Margin significantly influences the price of stock and Return on Equity (ROA) remarkably affects the quantity of issued stock.
\end{abstract}

\section{KEY WORDS}

Internal variables, banking, capital market development, market capitalization, Indonesia Stock Exchange.

The Indonesian capital market has run for 106 years and is once closed and vacuum until 1977. The capital market is reactivated in the New Order era (August 10, 1977). In that period, trade in the stock exchange is still sluggish since foreign investors are still prohibited from entering and companies' interest in registering their stock is still quite low. In 1988, the stock exchange is open for foreign investors, thus the trade in the stock exchange increases. This development of stock exchange market cannot be separated from the Government's efforts in making corrections, such as: a). in 1992 the JSX officially became a private company (privatized). BAPEPAM has been redesigned as the Capital Market Supervisory Agency; two years later, in 1995, a trade automation system is made with the Jakarta Automated Trading System JATS Computer System; and in 1997, Depository and Settlement Institute (LPP) is established under the name of PT. Kustodian Sentral Efek Indonesia (KSEI) assigned to provide custody service for various securities and settlement of security transactions. b). in 2000 the Jakarta Stock Exchange applied a scripless system of trading.

Table 1 - The Performance of price index, Market Capitalization, Issuer and Capital Investor

\begin{tabular}{|c|c|c|c|c|c|}
\hline Year & $\begin{array}{c}\text { Final IHSG } \\
(\mathrm{Rp})\end{array}$ & $\begin{array}{c}\text { Market Capitalization } \\
\text { (trillion Rp) }\end{array}$ & $\begin{array}{c}\text { Issuers/ } \\
\text { Companies }\end{array}$ & $\begin{array}{c}\text { Regular Market Stock } \\
\text { Volume (Million) }\end{array}$ & Investor \\
\hline 2014 & $5,226.947$ & $5,228.043$ & 506 & $899,939.80$ & 364,465 \\
\hline 2015 & $4,593.01$ & $4,872.701$ & 521 & $933,022.35$ & 437,197 \\
\hline 2016 & $5,296.71$ & $5,753.612$ & 537 & $1,305,398.24$ & 894,116 \\
\hline 2017 & $6,355.65$ & $7,052.39$ & 566 & $1,829,770.28$ & $1,122,668$ \\
\hline 2018 & $6,194.498$ & $7,023.50$ & 619 & $1,706,969.13$ & $1,676,606$ \\
\hline
\end{tabular}

Source: BEI, 2018

Fast forward, in 2002 the Jakarta Stock Exchange conducted a remote trading system and in 2007 the merger of the Surabaya Stock Exchange (BES) and Jakarta Stock Exchange (BEJ) became what we know now as the Indonesia Stock Exchange. c). in 2009, New Trading System of PT Bursa Efek Indonesia: JATS-NextG was launched; in 2012, a capital market trading infrastructure is built with a Straight Through Processing (STP) system; and in 2013, IDX obtained a business license as an organizer of the Indonesian Securities Investor 
Protection Program (P3IEI) to increase investor confidence in investing in the Indonesian capital market. d). in 2015: the launch of IDX Channel and the Launch of an XBRL based Financial Statement Reporting System; and in 2017, the launch of Derivative Product of Indonesia Government Bond Future and the implementation of Electronic Trading Platform.

Based on table 1 above, the Indonesia Stock Exchange has its mean growth of market capitalization of $8.22 \%$, mean growth of issuers of $5.2 \%$ and the highest mean growth in 2016 of $104.5 \%$. The data show that the Indonesian capital market keeps growing amidst the slowdown of the world economy. To win the competition and maintain investors' trust in the capital market, BEI continuously attempts to improve the trade infrastructure, strengthen supervision over and fostering of market makers, as well as protect and serve investors' interest as best it can.

Another thing that affects market growth and development is government support, infrastructure and financial performance from the company. The capital market development is shown by stock price, the quantity of company, investor numbers, outstanding shares and stock market capitalization.

The influence of companies' financial performance on capital market developments was investigated by: Muhammad Atiq et al. (2010), Muhammad Azam and Duresh Kumar (2011), Placido M. Menaje, Jr (2012, Md. Reaz Uddin, et al. (2013), Menike M. G. P. D.and U. S. Prabath (2014),), Anita and Pavitra Yadav (2014), and Muhammad Zulqarnain JATO et al. (2014), Dr. Munther Al-Nimer and Dr. Nimer Alslihat (2015), Linda Dwi Roswitasari et al. (2015), Taimur Sharif et al. (2015), Oliver Ike Inyiama and Caroline Ozouli (2015), I Gusti Ayu Purnamawati (2016), Samuel Tabot Enow and Pradeep Brijlal (2016), Thomas Arkan (2016), Mubashir Qurashi and Muhammad Zahoor (2016) and Williams Abayaawien Atuilik and Hussein Salia(2018).

In this paper, the author is going to study what form of correlation exists between the Return on Asset (ROA), Return on Equity (ROE), Capital Adequacy Ratio (CAR), Earning per share (EPS), Net Interest Margin (NIM), Debt to Total Assets (DTA),Non-Performing Loan (NPL), and Loan to Deposits Ratio (LDR) of the companies listed at BEl and stock price, issued stock and stock market capitalization.

This research is conducted with the Bursa Efek Indonesia or Indonesia Stock Exchange (BEI) in a consideration that the BEI is a stock exchange which remains developing and still needs researches for information whether stock price, amount of issued stock and market capitalization are influenced by issuers' financial performance indicator.

\section{LITERATURE REVIEW}

Based on the regulation of PBI No 15/12 / PBI / 2013, minimum capital requirement for commercial banks are set at $8 \%$ and the Circular Letter of Bank Indonesia No. 6/23/DPNP in 2004 , the criteria of a bank CAR were categorized as very healthy if the CAR is $>12 \%$, healthy if CAR ranges from $9 \% \leq$ CAR $<12 \%$, fairly healthy if CAR value is between $8 \% \leq$ CAR $<9 \%$, less healthy if CAR value is $6 \%<C A R<8 \%$ and unhealthy if the CAR value is $\leq$ $6 \%$. According to Petersen (2008) and Irwan $\mathrm{CH}$ (2017); banks must have capital that is higher than the minimum amount that has been set, while Yolanda (2017) defines CAR as a measurement of adequacy of bank capital to secure risk exposures. Thus, it can be said that the ratio exhibiting the size to determine the adequacy of bank capital if it experiences shock is called CAR. The formula of ROA contained in attachment SEOJK No.14 / SEOJK.03 / 2017 and Bank Indonesia Circular No. 13/30 / DPNP December 16, 2011 are:

$$
\text { Return on Asset }(\mathrm{ROA})=\text { Profit after Tax } / \text { Total Asset }(\text { mean })
$$

ROA provides an illustration of how efficiently management uses its assets to generate profits or it can be said that it is employed to estimate capability of the certain company to make gain or profit both in the past and in the future. And based on that, Theresia Vania Hamoli and Nila Firdaus Nuzula (2018) affirmed that excellent rate of ROA is higher than 1, 5 and the bad value is lower than zero. 
Brigham \& Ehrhardt (2005) states Return on Equity (ROE) can give investors an idea as an investment opportunity, Hansen and Mowen (2012) states the ratio between total equity and net income after tax and Higgins (2012) states as a measure of efficiency used by companies in using owner's capital. While Yolanda (2017 and 2018), stated the capability of the company to make profits with the equity it has. According to the Circular Letter of Bank Indonesia No. 13/30/DPNP December 16, 2011, formulation of Return on Equity (ROE) is shown below:

$$
\begin{gathered}
\text { Return on Equity }=\text { Profit after Tax } / \text { Total Equity (mean) } \\
\text { or } \\
\text { ROE }=\text { ROA } \times \text { Financial Leverage } \\
\text { Financial Leverage }=\text { Assets } / \text { Shareholders Equity }
\end{gathered}
$$

Earnings per share is one indicator used by investors as a basis for selecting shares to be bought, because it can reflect the value of the profits to be obtained from ownership of these shares. Besides that EPS also shows how profitable the company is for shareholders. According to Pankaj Kumar (2017), Earning per share can be a very strong predictor of stock prices.

Debt to Total Assets (DTA) functions as an estimation of the total debt to total assets. Also, it displays state of which companies have used debt to fund assets and according to Rasa Subačienè and Liuda Villis (2010), the ratio shows quantity of company assets financed by loans and the ratio should not be more than $0.7(70 \%)$ and the best is 0.3 . When a ratio is higher than 1 , the majority of debt is financed with assets or the company has more obligations than the assets it has. The state of high ratio may describe that the company is at risk of failing to pay its debt in case of suddenly increasing interest rate. If the ratio is below, 1 most of company's assets are funded by equity.

Pursuant to Attachment SEOJK No.14/SEOJK.03/2017, NIM value is obtained from: Net Interest Income divided with Mean Productive Assets $\times 100 \%$. NIM value higher than 3\% is considered very good and NIM lower or equal to $1 \%$ is considered bad.

This ratio is used to examine bank management's ability in managing productive assets to generate net profit. Higher NIM value shows that the bank is able to generate big interest, which will influence the profitability.

Non-Performing Loans (NPL) is correlated with risk of defaulted repayment of financing provided by bank. Criteria for the NPL value of a very healthy bank is small than $2 \%$, healthy is $2 \% \leq \mathrm{NPL}<5 \%$, quite healthy is $5 \% \leq \mathrm{NPL}<8 \%$, less healthy between $8 \%$ and $12 \%$ and unhealthy is greater than $12 \%$ (Circular Letter of Bank Indonesiano.6/23/DPNP/2004).

Regulation of Bank Indonesia (PBI) No. 13///PBI/2011 article 2 regardingLoan to Deposits Ratio (LDR), it is the measurement used to decide state of banks by Bank Indonesia. Perregulation in 2004, issued by Circular Letter of Bank Indonesia No. 6/23/DPNP concerning the health criteria of a bank. The banking health criteria are; very healthy withLDR $\leq 75 \%$, healthy with $75 \%<$ LDR $\leq 85 \%$, fairly healthy ranging from $85 \%<$ LDR $\leq$ $100 \%$, the value of LDR in less healthy state indicated between $100 \%<\mathrm{LDR} \leq 120 \%$, and unhealthy LDR with value of $>120 \%$.

The price of saleable stock is diagnosed from supply and demand activities from the relevant stock within capital market. In case the demand of stock surges, then the share price surges or otherwise, if demand of stock plunges, then share price also plunges. Based on company's fundamental analysis, if a company generates higher profit than the same previous period, the more likely prospective share buyers will purchase the company's shares, which triggers stock price to increase and if a company fails to have record profit/loss, investors will avoid buying the stock, which may cause them to sell the stock for fear of suffering loss.

The value of total market of all issued stocks of companies existing in the capital market, thus market capitalization may be calculated by multiplying current market price of 
companies' stocks and companies' total stocks is defined as market capitalization. The formula of market capitalization is:

$$
\mathrm{Vs}=\mathrm{Ps} \times \mathrm{Ss}
$$

Where: $\mathrm{Vs}=$ Market capitalization; $\mathrm{Ps}=$ Market price; $\mathrm{Ss}=$ Total issued stocks.

Hypothesis. To answer the problem above and accomplish the research objective, the following hypotheses are arranged:

$\mathrm{H}_{1}$ : Simultaneously and partially, Return on Asset (ROA), Earning per share (EPS), Return on Equity (ROE), Debt to Total Assets (DTA), Capital Adequacy Ratio (CAR), Net Interest Margin (NIM), Non-Performing Loans (NPL) and Loan to Deposits Ratio (LDR) significantly influence stock price.

$\mathrm{H}_{2}$ : Simultaneously and partially, Return on Asset (ROA), Earning per share (EPS), Return on Equity (ROE), Debt to Total Assets (DTA), Capital Adequacy Ratio (CAR), Net Interest Margin (NIM), Non-Performing Loans (NPL) and Loan to Deposits Ratio (LDR) significantly influence Amount of issued stock.

$\mathrm{H}_{3}$ : Simultaneously and partially, Return on Asset (ROA), Earning per share (EPS), Return on Equity (ROE), Debt to Total Assets (DTA), Capital Adequacy Ratio (CAR), Net Interest Margin (NIM), Non-Performing Loans (NPL) and Loan to Deposits Ratio (LDR) significantly influence Market Capitalization.

\title{
METHODS OF RESEARCH
}

The purpose of this research is to testing the effect of Capital Adequacy Ratio $(\mathrm{CAR}=\mathrm{X} 1)$, Return on Asset $(\mathrm{ROA}=\mathrm{X} 2)$, Return on Equity $(\mathrm{ROE}=\mathrm{X} 3)$, Earning per share (EPS $=X 4)$, Debt to Total Assets (DTA=X5),Net Interest Margin (NIM=X6), Non-Performing Loans $(\mathrm{NPL}=\mathrm{X} 7)$ and Loan to Deposits Ratio (LDR=X8) on stock price (Y1), Issued stock (Y2) and Market Capitalization (Y3).

The research period is six years of financial statement consecutively published from 2011 to 2017 of 25 banks recorder on BEI. The analysis employs Eviews software and hypothesis test (f test and t test), descriptive statistic test, classical assumption test, multiple linear regression (Panel data regression equation with One Way Model) and chow test/ Hausman test and determination coefficient test. The regression equation in this research is:

\begin{abstract}
Equation Model 1: $\mathrm{Y} 1=\mathrm{a}+\mathrm{b} 1 \mathrm{X} 1+\mathrm{b} 2 \mathrm{X} 2+\mathrm{b} 3 \mathrm{X} 3+\mathrm{b} 4 \mathrm{X} 4+\mathrm{b} 5 \mathrm{X} 5+\mathrm{b} 6 \mathrm{X} 6+\mathrm{b} 7 \mathrm{X} 7 \mathrm{~b} 8 \mathrm{X} 8+\mathrm{e}$ Equation Model 2: $Y 2=a+b 1 X 1+b 2 X 2+b 3 X 3+b 4 X 4+b 5 X 5+b 6 X 6+b 7 X 7 b 8 X 8+e$ Equation Model 3: $Y 3=a+b 1 X 1+b 2 X 2+b 3 X 3+b 4 X 4+b 5 X 5+b 6 X 6+b 7 X 7 b 8 X 8+e$
\end{abstract}

\section{RESULTS AND DISCUSSION}

Given the results of Chow and Hausman test on the first equation model, it is fixed effect. Based on the equation model, Capital Adequacy Ratio (CAR) shows significant plus negative effects on price of stock, it is not in accordance with the research by Linda Dwi Roswitasari et al (2015) and M. Irawan Noor and Pujionolmar Rosyid (2018). While Return on Assets (ROA) significantly influences stock price. The same also occurs on the results of researches conducted by Fouzan AI Qaisi et al. (2016), Dr. Majed Abdel Majid Kabajeh, et al. (2012), Parviz Saeidi and Abolghasem Okhli (2012), as well as Hidayat Ihsan Abditama and Sylviana Maya Damayanti (2015). Meanwhile, Muhammad Yasir Naveed and Muhammad Ramzan (2013) and Wiwi Idawati and Aditio Wahyudi (2015) state that ROA shows influence which is not significant on price of share.

Consecutively, results above also display that ROE show sinsignificant effect on stock prices, as probed byFouzan Al Qaisi et al. (2016) and Junjie Wang et al. (2013). Forvariable of earning per share (EPS) to the price of share is insignificant, also is supported by Md. Rashidul Islam et al. (2014), Ms. Sujeewa Kodithuwakku (2016) and Lina Hani Warrad (2017).Meanwhile, the results of researches conducted by Faris Nasif AL- Shubiri (2010), 
Junjie Wang et al. (2013), Nidhi Malhotra and Kamini Tandon (2013), Md. Shariful Islam et al. (2015), Ahamed Lebbe Abdul Rauf (2015), E.Geetha and Ti. M. Swaaminathan (2015), Maryyam Anwaar (2016), and Budhi Suparningsih (2017) state that earning per share significantly influences stock price. Natasha Robbetze (2017) divides EPS into basic, diluted and main, and the research result shows that basic EPS has the best correlation with the behavior of change in stock price compared with diluted EPS.

The influence of Debt to Total Asset (DTA) with the price of stock in this study is also insignificant, but results of the study conducted by Seyed Javad Mosavi Nahoji et al (2014) are influential. While Net Intrest Margins (NIM) and Non-Performing Loans (NPL) in this study also have significant and positive effects, as corroborated by other research results of Firas Na'el Rawhi Hashem et al (2017) for NPL and Budhi Suparningsih (2017) for Net Intrest Margins (NIM).

According to the research performed by Zakaria et al. (2015), Non-Performing Loans (NPL) and Loan to Deposit Ratio (LDR) influence Stock Price Index of Banking Industry in $\mathrm{BEI}$, conforming to research results obtained. Meanwhile, Pujionolmar Rosyid and M. Irawan Noor (2018) also state that Loan to Deposit Ratio (LDR) significantly influences price of stock.

The results above simultaneously imply that the contribution of CAR, ROA, ROE, EPS, DTA, NIM, NPL and LDR to stock price is $55.39 \%$, as shown by Adjusted R-squared = 0.553872 . Meanwhile, the $44.61 \%$ of stock price movement is influenced by other unstudied factor.

This model shows that if CAR and EPS increase, stock price will decrease. On the contrary, if ROA, ROE, DTA, NIM, NPL and LDR increase, stock price will also increase, since they have positive correlation.

The regression equation is:

$$
\begin{gathered}
\mathrm{Y} 1=1930.516-0.116142(\mathrm{CAR})+0.006236(\mathrm{ROA})+0.007142(\mathrm{ROE})-0.128228(\mathrm{EPS})+ \\
0.109033(\mathrm{DTA})+0.044409(\mathrm{NIM})+1.908525(\mathrm{NPL})+5.508075(\mathrm{LDR})+\mathrm{e}
\end{gathered}
$$

Based on the equation above, we may conclude that CAR negatively and significantly influences, while EPS negatively and insignificantly influences stock price. All other variables positively influence it.

For the second equation, given the results of Chow and Hausman test, the model selected to predict price amount of issued stock is the fixed effect model. The research exhibits that CAR, ROA, ROE, NPL and LDR significantly influence the amount of issued stock, while EPS, DTA and NIM do not significantly influence it. Based on the model above, CAR, ROE, EPS, DTA and LDR are negatively correlated with the amount of issued stock, which means that an increase of CAR, ROE, EPS, DTA as well as LDR will result in decreasing amount of issued stock, while the simultaneous influence of all variables on the amount of issued stock is significant. The four (8) dependent variables only influence the amount of issued stock at $51.30 \%$, while the remainder is influenced by other unstudied variable. The regression equation is:

$$
\begin{gathered}
\mathrm{Y} 2=107.4154-0.180663(\mathrm{CAR})+0.009333(\mathrm{ROA})-0.480538(\mathrm{ROE})-0.136539(\mathrm{EPS})- \\
0.126690(\mathrm{DTA})-0.052819(\mathrm{NIM})+4.180477(\mathrm{NPL})-9.644696(\mathrm{LDR})+\mathrm{e}
\end{gathered}
$$

According to the equation, we may observe that ROA and NPL positively influence issued stock, while the other factors influence it negatively.

According to the testing results of the 3rd equation model as well as the results of Chow and Hausman test, the researchers selected random effect model. From the research results obtained that CAR, ROA, EPS and DTA significantly influence market capitalization, while ROE, NIM, NPL, and LDR show insignificant influence on market capitalization.

The research results of Munther Al-Nimer and Nimer Alslihat (2015) show that ROE and ROA exhibits positive as well as significant effect on market capitalization, while Mubashir Qurashi and Muhammad Zahoor (2016), stated that they do not show any effect on 
market capitalization. Anita and Pavitra Yadav's research results (2014); market capitalization and earnings per share are insignificant and Muhammad Zulqarnain JATO et al (2014) affirms that EPS display significant effect on the Market Value of Share.

$$
\begin{gathered}
\mathrm{Y} 3=0.242780+0.084215(\mathrm{CAR})+0.001505(\mathrm{ROA})+0.001498(\mathrm{ROE})+0.074434(\mathrm{EPS})- \\
0.067742(\mathrm{DTA})+0.002674(\mathrm{NIM})+0.023632(\mathrm{NPL})-0.069374(\mathrm{LDR})+\mathrm{e}
\end{gathered}
$$

According to the equation, we may observe that DTA and LDR variables negatively influence market capitalization, while the other variables influence it positively.

\section{CONCLUSION}

The capital market development may be indicated from the price of stock, the shares outstanding number and the valued of market capitalization, while financial performance variables of companies recorded on $\mathrm{BEI}$ are shown by Return on Equity (ROE), Return on Assets (ROA), Capital Adequacy Ratio (CAR), Net Interest Margin (NIM), Earning per share (EPS), Debt to Total Assets (DTA), Loan to Deposits Ratio (LDR), and Non-Performing Loans (NPL).

Aforementioned results also show that ROE, EPS, and DTA do not significantly affect price of stock and EPS, variables of DTA and NIM show no influence on issued stock, whereas ROE, NIM, NPL and LDR do not significantly influence market capitalization.

The ratio that displays adequacy of bank capital if it experiences shock is called Capital Adequacy Ratio (CAR), while the capability of certain company to make gain or profit both in the past and in the future is the definition of Return On Assets (ROA. Based on this, two variables are often used as a decision tool for investors to see the development of the capital market.

EPS and DTA do not significantly influence stock price and issued stock, but significantly influence market capitalization. This shows that capital market development with market capitalization as the indicator is highly influenced by the value of profit to be obtained by investor from shareholding (EPS) and company's amount of assets which may be funded with loan (DTA). In case the profit obtained from shareholding and company's amount of assets is too high, it will influence capital market development with Market Capitalization as the indicator.

\section{REFERENCES}

1. Anita and Pavitra Yadav (2014), "Influence Of Selected Financial Indicators On Stock Price Of Tata Motors Ltd", International Journal of Application or Innovation in Engineering \& Management (IJAIEM), Volume 3, Issue 7, July 2014, p. 249-252.

2. Anwaar Maryyam (2016), "Impact of Firms' Performance on Stock Returns (Evidence from Listed Companies of FTSE-100 Index London, UK)", Global Journal of Management and Business Research: Accounting and Auditing, Volume 16 Issue 1, p. 30-39.

3. Arkan Thomas (2016), "The Importance of Financial Ratios in Predicting Stock Price Trends: A Case Study in Emerging Markets", Finanse, Rynki Finansowe, Ubezpieczenia nr 1/2016 (79), p. 13-26.

4. Atuilik Williams Abayaawien and Hussein Salia (2018), "The Importance of financial reporting to capital market development in Ghana", Journal of Economics and International Finance, Vol. 10(8), p. 89-94.

5. Atiq Muhammad, Muhammad Rafiq, Roohullah (2010), "Factors Affecting Stock Prices: A Case Study Of Karachi Stock Exchange (Kse)", B\&ER Vol. 2, No. 1, 2010, p. 7-12.

6. Azam Muhammad and Duresh Kumar (2011),"Factors Influencing the Individual Investor and Stock Price Variation: Evidence from Karachi Stock Exchange", Australian Journal of Basic and Applied Sciences, 5(12): p. 3040-3043.

7. Bursa Efek Indonesia, Tahun 2011-2018. 
8. Dadrasmoghadam Amir and Seyed Mohammad Reza Akbari (2015)," Relationship between Financial Ratios in the Stock Prices of Agriculture-Related Companies Accepted On the Stock Exchange for Iran", Research Journal Of Fisheries And Hydrobiology, 10(9) May 2015, p. 586-591.

9. Enow Samuel Tabot and Pradeep Brijlal (2016),"Determinants of Share Prices: the Case of Listed Firms on Johannesburg Stock exchange", Journal of Accounting and Management vol. 6, no. 1(2016), p. 85-92.

10. Hashem FirasNa'el Rawhi, Khalid Ali Ahmad Alduneibat \& Mohammad Abdallah Fayadaltawalbeh (2017)," The Impacts of Non-Performing Loans upon the Prices of Stocks in Jordanian Commercial Banks", Accounting and Finance Research Vol. 6, No. $1 ; 2017$, p. 139-147.

11. Hidayatlhsan Abditama and Sylviana Maya Damayanti (2015),"The Influence of Company Performance Toward Stock Price Of Pt. XI Axiata Tbk From 2008 - 2014", Journal Of Business And Management Vol. 4, No.4, 2015: p. 510-521.

12. Hashem FirasNa'el Rawhi, Khalid Ali Ahmad Alduneibat\& Mohammad Abdallah Fayadaltawalbeh (2017)," The Impacts of Non-Performing Loans upon the Prices of Stocks in Jordanian Commercial Banks", Accounting and Finance Research Vol. 6, No. $1 ; 2017$, p. 139-147.

13. Higgins, R. C. (2012). Analysis for financial management (10th ed.). New York, NY: McGraw-Hill.

14. Irwan $\mathrm{CH}$, (2017), "The Effect of Financial Ratios on Islamic Rural Bank Performance In Indonesia", International Journal Of Scientific \& Technology Research Volume 6, Issue 08, August 2017, p. 384-390.

15. Idawati Wiwi and Aditio Wahyudi (2015),"Effect of Earning Per Shares (EPS) and Return On Assets (ROA) against Share Price on Coal Mining Company Listed in Indonesia Stock Exchange", Journal of Resources Development and Management www.iiste.org ISSN 2422-8397, Vol.7, 2015, p. 79-92.

16. Inyiama Oliver Ike and Caroline Ozouli (2015),"Does Earning Per Share Determine Market Price Of Ordinary Shares? Evidence from Nigeria Banking Sector (2000 - 2013)", European Journal of Accounting Auditing and Finance Research Vol.3, No.7, pp.21-32.

17. Kodithuwakku Ms. Sujeewa (2016),"Impact of Firm Specific Factors on the Stock Prices: A Case Study on Listed Manufacturing Companies in Colombo Stock Exchange", International Journal for research in Business, Management and Accounting, Vol 2 Issue 3, ISSN : 2455-6114, p. 67-76.

18. Islam Md. Shariful, Mohammad Abdus Salam and Md. Mahmud Hasan (2015),"Factors Affecting the Stock Price Movement: A Case Study on Dhaka Stock Exchange", International Journal of Business and Management; Vol. 10, No. 10; 2015, ISSN 18333850 E-ISSN 1833-8119, p. 253-262.

19. Kabajeh Majed Abdel Majid, Said Mukhled Ahmed AL Nu'aimat and Dr. Firas Naim Dahmash ( 2012),"The Relationship between the ROA, ROE and ROI Ratios with Jordanian Insurance Public Companies Market Share Prices", International Journal of Humanities and Social Science Vol. 2 No. 11; June 2012, p. 115-120.

20. Kumar Pankaj (2017), "Impact Of Earning Per Share And Price Earnings Ratio On Market Price Of Share: A Study On Auto Sector In India", International Journal of Research - Granthaalayah, Vol.5 (Iss.2, p. 113-118.

21. Menike M. G. P. D.and U. S. Prabath ( 2014)," The Impact of Accounting Variables on Stock Price: Evidence from the Colombo Stock Exchange, Sri Lanka", International Journal of Business and Management; Vol. 9, No. 5; 2014, ISSN 1833-3850 E-ISSN 1833-8119, p. 125-137.

22. Menaje Jr Placido M. (2012),"Impact of Selected Financial Variables on Share Price of Publicly Listed Firms in the Philippines", American International Journal of Contemporary Research Vol. 2 No. 9; September 2012, p. 98-104.

23. Noor M. Irawan and Pujionolmar Rosyid (2018),"Effect of Capital Adequacy Ratio (CAR), Loan to Deposit Ratio (LDR) and Return on Equity (ROE) on Share Price PT Bank 
Danamon Indonesia, TBK", International Journal of Business and Applied Social Science (IJBASS) VOL: 4, ISSUE: 1, p. 87-101.

24. Nahoji Seyed Javad Mosavi, Dr. Hossein Rezaee Dolat Abadi and Dr. Batol Rafat (2014), "The Relationship between Stock Prices and Debt Ratio And Capital Flows With Assets", Interdisciplinary Journal Of Contemporary Research In Business VOL 6, NO 1, p. 34-43.

25. Nimer Munther Al and Nimer Alslihat (2015), The Effect of Profitability Ratios on Market Capitalization in Jordanian Insurance Companies Listed in Amman Stock Exchange", Journal of Economics and Sustainable Development, Vol.6, No.6, p.140-146, ISSN 22221700 (Paper) ISSN 2222-2855 (Online).

26. Naveed Muhammad Yasir and Muhammad Ramzan (2013),"A View About The Determinants Of Change In Share Prices: A Case From Karachi Stock Exchange (Banking Sector)", Interdisciplinary Journal Of Contemporary Research In Business, Vol 4, No 12, p. 41-57.

27. Rauf Ahamed Lebbe Abdul (2015),"What Determine Share Prices? Evidence From Banking Sector Listed In Colombo Stock Exchange", 5th International Symposium 2015 IntSym 2015, SEUSL, p. 29-31.

28. Rashidul Islam Md, Tahsan Rahman Khan, Tonmoy Toufic Choudhury and Ashique Mahmood Adnan(2014), "How Earning Per Share (EPS) Affects on Share Price and Firm Value", European Journal of Business and Management, Vol.6, No.17, p. 97-108.

29. Robbetze Natasha, Rikus de Villiers and Lana Harmse (2017), "The Effect Of Earnings Per Share Categories On Share Price Behaviour: Some South African Evidence", The Journal of Applied Business Research, Volume 33, Number 1, p. 141-151.

30. Roswitasari Linda Dwi, Noer Azam Achsani and Trias Andati (2015),"Banking Subsector: Performance Ratio Influence to Bank's Stock Prices during the Period 2010 - 2014", International Journal of Science and Research (IJSR), Volume 6 Issue 2, February 2017, p. 627-633.

31. Petersen. J. Mukuddem, Petersen. M.A., (2008). Optimizing asset and capital adequacy management in banking. Journal Option Theory Appl, 137, p. 205 - 230. DOI 10.1007/s10957-007-9322-x

32. Purnamawati I Gusti Ayu (2016),"The Effect Of Capital Structure And Profitability On Stock Price (Study Of The Manufacturing Sector In Indonesia Stock Exchange)", International Journal of Business, Economics and Law, Vol. 9, Issue 1.p. 10-16.

33. Otoritas Jasa Keuangan, $2011-2018$

34. Qurashi Mubashir and Muhammad Zahoor (2016), "Impact of profitability, bank and macroeconomic factors on the market capitalization of the Middle Eastern banks", International Journal of Business and Management Invention, Volume 5 Issue 11, P-5662, ISSN (Online): 2319 - 8028, ISSN (Print): 2319 - 801X, https://www.ijbmi.org/papers/Vol(5)11/version-2/E051102056062.pdf

35. Qaisi Fouzan Al, Asem Tahtamouni and Mustafa AL-Qudah (2016)“Factors Affecting the Market Stock Price - The Case of the Insurance Companies Listed in Amman Stock Exchange", International Journal of Business and Social Science Vol. 7, No. 10; October 2016, p. 81-90.

36. Sharif Taimur, Harsh Purohit \& Rekha Pillai (2015),"Analysis of Factors Affecting Share Prices: The Case of Bahrain Stock Exchange", International Journal of Economics and Finance; Vol. 7, No. 3; 2015, p. 207-216.

37. Suparningsih Budhi (2017), "Effect of debt to equity ratio (DER), price earnings ratio (PER), net profit margin (NPM), return on investment (ROI), earning per share (EPS) In influence exchange rates and Indonesian interest rates (SBI) share price in textile and garment industry Indonesia stock exchange", International Journal of Multidisciplinary Research and Development, Volume 4; Issue 11, P. 58-62.

38. Shubiri Faris Nasif AL (2010),"Analysis the Determinants of Market Stock Price Movements: An Empirical Study of Jordanian Commercial Banks", International Journal of Business and Management Vol. 5, No. 10; October 2010, p. 137-147.

39. Swaaminathan E. Geetha and Ti. M. (2015),"A study on the factors influencing stock price A Comparative study of Automobile and Information Technology Industries stocks 
in India ", International Journal of Current Research and Academic Review Volume 3 No. 3. P. 97-109.

40. Saeidi Parviz and Abolghasem Okhli (2012), "Studying the effect of assets return rate on stock price of the companies accepted in Tehran stock exchange", Business and Economic Horizons Volume 8, Issue 2, December 2012, ISSN: 1804-1205, p. 12-22.

41. Subačienè Rasa and Liuda Villis (2010), "A System of Analysis of the Total Liabilities to Total Assets Ratio", Ekonomika 2010 Vol. 89(2), ISSN 1392-1258, p. 120-129.

42. Suparningsih Budhi (2017), "Effect of debt to equity ratio (DER), price earnings ratio (PER), net profit margin (NPM), return on investment (ROI), earning per share (EPS) In influence exchange rates and Indonesian interest rates (SBI) share price in textile and garment industry Indonesia stock exchange", International Journal of Multidisciplinary Research and Development Online ISSN: 2349-4182, Print ISSN: 2349-5979, Volume 4; Issue 11; September 2017; P. 58-62.

43. Tandon Nidhi Malhotra and Kamini (2013),"Determinants of Stock Prices: Empirical Evidence from NSE 100 Companies", International Journal of Research in Management \& Technology (IJRMT), ISSN: 2249-9563 Vol. 3, No.3, June 2013, p. 86-95.

44. Uddin Md. Reaz, S.M. Zahidur Rahman and Md. Rajib Hossain (2013), "Determinants of Stock Prices in Financial Sector Companies in Bangladesh- A Study on Dhaka Stock Exchange (DSE)", Interdisciplinary Journal Of Contemporary Research In Business Vol 5, No 3, p. 471-480.

45. Vania Hamolin Theresia and Nila Firdaus Nuzula (2018), "Analisis Tingkat Kesehatan Bank Berdasarkan Metode Risk Based Bank Rating (Studi Pada Bank Umum Konvensional Di Indonesia Periode 2014-2016), "Jurnal Administrasi Bisnis (JAB)|Vol. 57 No. 1 April 2018, p. 218- 226.

46. Warrad Lina Hani (2017), "The Effect of Market Valuation Measures on Stock Price: An Empirical Investigation on Jordanian Banks", International Journal of Business and Social Science Vol. 8, No. 3; March 2017, p. 67-74.

47. Wang Junjie, Gang Fu and Chao Luo1 (2013)," Accounting Information and Stock Price Reaction of Listed Companies - Empirical Evidence from 60 Listed Companies in Shanghai Stock Exchange", Journal of Business \& Management Volume 2, Issue 2 (2013), 11-21 ISSN 2291-1995 E-ISSN 2291-2002, p. 11-21.

48. Williams Abayaawien Atuilik and Hussein Salia (2018), "The Importance of financial reporting to capital market development in Ghana", Journal of Economics and International Finance, Vol. 10(8), DOI: 10.5897/JEIF2017.0840, p. 89-94.

49. Yolanda (2017)", Capital Adequacy Ratio and Its Influencing Factors On the Islamic Banking in Indonesia", Journal of Islamic Economics and Business, Volume 2, No 2 (2017), p. 162 - 176.

50. Yolanda and Sumarni (2018), "Financial Performance and Factors Influencing Its Banking Companies in Indonesia Stock Exchange", Russian Journal of Agricultural and Socio-Economic Sciences (RJOAS), 3(75), March 2018, DOI https://doi.org/10.18551/rjoas.2018-03.07, p. 63-72. 